\title{
Summaries of Doctoral Dissertations
}

\section{The Economic Role of the English Poor Law, 1780-1834}

Over the 85 -year period from $1748 / 50$ to $1832 / 34$, real per capita expenditures on poor relief increased at an average rate of approximately 1 percent per year. ${ }^{1}$ There were also important changes in the administration of relief with respect to able-bodied laborers during the period. Policies providing relief outside of workhouses to unemployed and under-employed able-bodied laborers became widespread during the 1770s and 1780s in the grain-producing South and East of England. The so-called Speenhamland system of outdoor relief flourished until 1834, when it was abolished by the Poor Law Amendment Act. The aim of the thesis is to provide an economic explanation for the long-term increase in relief expenditures and for the development and persistence of Speenhamland policies.

The traditional analysis of the Speenhamland system is largely derived from the 1834 Report of the Royal Commission to Investigate the Poor Laws. It maintains that Speenhamland was an emergency response to the extremely high food prices of 1795 , which caused real wage rates in rural areas to temporarily fall below the subsistence level. The fear of a laborers' revolt (spawned by the French Revolution) led farmers to respond to the harvest crisis by creating a system of outdoor relief that guaranteed laborers a minimum standard of living near the subsistence level. Unfortunately, according to the traditional literature, the use of outdoor relief had massive disincentive effects on labor supply. Thus, in the long run, Speenhamland policies created unemployment, lowered the productivity of laborers that remained employed, and caused laborers' wages, farmers' profits, and landlords' rents to decline. The traditional literature offers no explanation for the persistence of outdoor relief until the passage of the Poor Law Amendment Act in 1834; the system is simply seen as self-perpetuating in nature.

A revisionist analysis of the economic role of the Old Poor Law began to take shape with the publication of two important papers by Mark Blaug in 1963 and 1964. The work of Blaug, Donald McCloskey, and Daniel Baugh refuted the hypothesis that Speenhamland policies had disastrous long-run consequences for the agricultural labor market. The revisionists, however, have not adequately explained why the system of outdoor relief became widespread in the late eighteenth century, why it was adopted over other methods of aiding poor laborers, or why it persisted until 1834. My thesis is an attempt to fill this void in the historical literature.

In order to determine why Speenhamland policies became widespread, one must first determine when the rapid increase in relief expenditures began. The traditional assumption that 1795 marked a watershed in relief administration is incorrect. Real per capita relief expenditures increased significantly faster from $1748 / 50$ to $1782 / 84$ than from $1782 / 84$ to $1832 / 34$ ( 1.42 percent versus 0.78 percent per year). It follows that outdoor relief was not an emergency response to the high grain prices of 1795 . Rather, I maintain that the rapid increase in relief expenditures was a response to two fundamental changes in the economic environment in the South and East of England: first, the prolonged increase in wheat prices that began in the early 1760 s and continued through the Napoleonic Wars, and second, the decline of cottage industry in the South as a result of the rise of industrial production in the Northwest. These changes in the economic

\footnotetext{
${ }^{1}$ The dissertation was completed at the University of Wisconsin under the direction of Jeffrey G. Williamson.
} 
environment led to important changes in the implicit labor contract between farmers and agricultural laborers. Prior to the late eighteenth century, grain-producing farmers offered laborers an implicit contract that included wage labor in agriculture during peak seasons, plots of arable and pasture land for subsistence farming, and year-long employment for women and children in cottage industry. The rapid increase in the relative price of wheat, in response to population growth, caused a sharp increase in the value of arable land, which in turn led to significant changes in the distribution of landholding in the grain-producing South. In areas where the open-field system still existed in 1750 , the redistribution was accomplished to a large extent by enclosures. In areas where the arable land had been enclosed before 1750, marginal land formerly left to agricultural laborers was reclaimed by its owners as high grain prices made it profitable to be brought under cultivation. The result was the same in both cases: a decline in the amount of land available for use by agricultural laborers.

The decline of the woolens industry in the South during the last third of the eighteenth century caused a sharp decline in wage rates and employment opportunities in cottage industry. As a result, women and children were left jobless for up to 11 months out of the year, and many adult males became unable to find employment during the winter months.

The combined effect of these changes in the economic environment was to create a class of rural families whose sole source of income was wage labor in agriculture. This created problems in grain-producing areas, where the demand for agricultural labor varied significantly across seasons. Data concerning movements of per capita relief expenditures and wage rates, combined with various pieces of qualitative evidence, suggest that grain-producing farmers responded to the altered economic environment by adopting outdoor relief policies to maintain unneeded laborers during slack seasons. I contend that the payment of unemployment benefits was the major function of Speenhamland policies throughout the period of about 1780 to 1834 .

In order to test the hypothesis that implicit labor contracts containing seasonal layoffs and outdoor relief represented an efficient method for securing an adequate peak-season labor force, I developed a simple implicit contracts model to compare alternative feasible labor contracts. Farmers are assumed to maximize profits subject to the constraint that any contract offered to workers must yield an expected utility large enough to keep laborers from migrating to urban industrial areas. The model assumes that labor-hiring farmers were politically dominant in southern agricultural parishes, and thus were able to choose whether or not to adopt Speenhamland policies. Moreover, labor-hiring farmers are assumed to pay only a proportion, $e(0<e \leq 1)$, of the total relief payments. Solving the model yields the conditions under which a contract containing layoffs and outdoor relief dominated alternative feasible contracts. It was found that Speenhamland-type contracts were dominant in areas where the marginal product of labor at full employment was close to zero during slack seasons. Evidence suggests that grain-producing parishes satisfied this condition but pastoral farming parishes did not. Thus, contracts containing Speenhamland policies dominated alternative contracts in the South and East, while year-long wage contracts were dominant in the pastoral West and North.

The implicit contracts model was empirically tested using data from the 1831 Census and the 1832 Rural Queries, a questionnaire distributed throughout rural England by the Royal Poor Law Commission, with responses from approximately 1,100 parishes. The Rural Queries contained 58 questions relating to the administration of poor relief, wage rates, and employment opportunities for adult males, females, and children; seasonal levels of unemployment; the existence of gardens and allotments for laborers; and the productivity of the labor force. Because of the interrelationship among relief expenditures, wage rates, and unemployment rates, a three-equation model to explain crossparish variations in per capita relief expenditures, family wage income, and unemployment rates was estimated. 
Overall, the results obtained provided substantial support for the implicit contracts model. Specialization in agriculture, the relative importance of grain production, and unemployment rates were found to have a significant positive impact on per capita relief expenditures. Although neither land allotments nor cottage industry had a significant impact on relief expenditures, both were found to have a significant negative impact on wage income, suggesting that farmers responded to the existence of allotments and cottage industry by reducing their laborers' wage income rather than by reducing relief expenditures. On the whole, the results suggest that labor-hiring farmers were indeed profit-maximizers who were willing (and able) to use the Poor Law to pass some of the cost of securing a peak-season labor force on to non-labor-hiring taxpayers.

The thesis concludes by reexamining the effect of the Settlement Law on rural-urban migration during the period of about 1780 to 1850 . According to the traditional literature, industrial parishes inhibited rural-urban migration by removing large numbers of nonsettled laborers during recessions. I contend, however, that the low experience rating faced by urban manufacturers, in combination with the general scarcity of urban labor, should have led the manufacturer-dominated Boards of Guardians to be anxious to grant relief to unemployed nonsettled laborers during cyclical downturns. In other words, urban parishes should have been quite selective in their use of the power of removal. Although this hypothesis could not be explicitly tested, it was possible to determine the occupations of persons removed from six Northwestern cities during the downturn of 1840 to 1842 . The overall removal rate of nonsettled persons who applied for relief during this period was between 10 and 15 percent. Only slightly more than onethird of the removals involved either skilled textile workers or unskilled laborers, whereas approximately 40 percent of the families removed were liable to be permanent charges on the parish. The results support the hypothesis that the threat of removal had only a slight impact on the rural-urban migration of able-bodied laborers.

The thesis provides an economic explanation for the adoption and persistence of policies granting outdoor relief to able-bodied laborers. Politically dominant labor-hiring farmers and manufacturers found implicit labor contracts containing seasonal layoffs and outdoor relief to be the cost-minimizing method for securing an adequate labor force. This result helps to explain why both rural and urban parishes continued to use outdoor relief long after it was abolished by Parliament in 1834. The thesis may also add to our understanding of how rural labor markets in general have responded to the onset of industrialization.

GEORge R. BOYER, Cornell University 